\title{
Interethnic Interaction Pattern in Karimunjawa Island
}

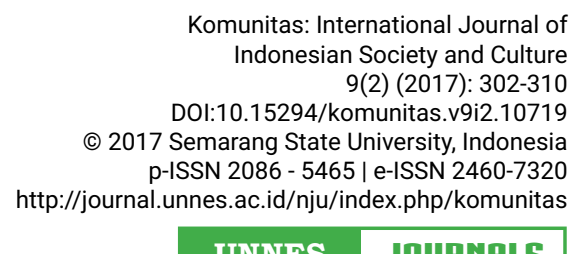

UNNDS

JOURNALS

\section{Titiek Suliyati ${ }^{1}$, Yety Rochwulaningsih, Mahendra P. Utama}

${ }^{1}$ Department of History Faculty of Humanities Diponegoro University, Indonesia

Received: March 2016; Accepted: August 2016; Published: September 2017

\begin{abstract}
This article discusses the interaction patterns in inter-ethnic life that inhabit Karimunjawa which is known to be very heterogeneous. Heterogeneity of Karimunjawa is not only seen in terms of the origin of the migrants, but also language and religion. There are nine ethnics, but three main ethnic inhabit Karimunjawa are, Javanese, Madurese and Buginese. Each develops different interaction patterns according to their ethnics. Nonetheless, the social values shared make Karimunjawa communities can live in harmony. They are affected by their perspectives on the sea as a common property right that can be used together regardless of the ethnic background and origin. Therefore, the pattern of harmonious interactions tolerates each other in equal style characterizing the community in Karimunjawa.
\end{abstract}

\section{Keywords}

interaction patterns; inter-ethnic; heterogeneous; island community; karimunjawa

\section{INTRODUCTION}

Karimunjawa is a sub district located in Jepara district, Central Javanese Province. The distance between Karimunjawa and Jepara city is approximately 45 nautical miles $( \pm$ $90 \mathrm{~km}$ ) by sailed through the Javanese Sea. Karimunjawa Sub District has a land area of 7,120 ha in the form of lowlands and hills (Pemerintah Karimunjawa 2014). As an archipelago, Karimunjawa sub district has great sea potential because most of its territory is in the form of sea. Thus this archipelago area has potential both in land and sea.

One thing that is also very interesting is that all the people are migrants. There is no native of Karimunjawa. At first, Karimunjawa was a stopover and resting place for sailors and traders who were on trading along the north coast of Javanese. This is possible because it is able to provide drinking water and other foodstuffs. In addition, this archipelago is also a resting place from the traveling between the north coast of Javanese and the south coast of Kalimantan. Initially, they came and then settled in Karimunjawa, so they can be called as a maritime tribe or ethnic group. Maritime ethnic in Karimunjawa islands is very heterogeneous as it comes from diverse ethnic backgrounds, namely the descent of; Buginese, Makassar, Mandarese, Bajauan, Banjarese, Butonese, Madurese, Batak and Javanese (Rochwula-

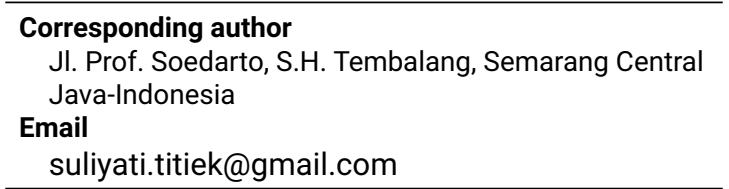


ningsih 2012). Nonetheless, the dominant ethnic is; Javanese, Madurese and Buginese. In the development, they experience changes both in the field of socio-economic and socio-cultural. An illustration of multiethnic community living in Karimunjawais Buginese community. If it is viewed from the background of cultural and economic activity, most of the Buginese are not sailors or fishermen, but merchants. This is different from the Mandarese who dominantly sail and has a livelihood as fishermen. Therefore, the trade by Buginese tribe is conducted using the sea route, consequently they also have to master the sea trade route. In the end, they are known as sailors (Pelras 2006). In overseas, they are known as people who have high work ethic and a hard worker. It is not infrequently that we see Buginese traders who success overseas (Paeni 1995). As a nomadic ethnic, Buginese always hold the philosophy that has been taught by their parents and ancestors (Kesuma 2004). Some philosophies which are still held in the life of Buginese community is palettui alemu riolo tejjokamu. It means that if you want to go abroad, you should know or make sure of a place where you go as well as the social environment and local culture. The nomads must have confidence that if they live overseas they are able to blend with the local environment (Hamid 2005). In addition, the Bugis people have social network established and developed among them as a successful immigrant has strongly established. (Muhammad, 2016).

Today, the Buginese communities generally have a livelihood as fishermen using the sailboat as a means of conveyance (Muhammad 2007). They are famous as a clever sailor in sailing. Buginese ability is not only limited to develop a sailboat and sailing, but also build ship. Historically, this ability is a hereditary heritage that forms historical landscape in areas where Bugis immigrants live. The ship builder ability can be traced from Bugis ethnic in one of their home regions in Sulawesi, as well as in Baubau Sulawesi (Syahadat, Arifin and Arifin, 2014). Almost all Javanese are also all good at fishing whether it is to find fish, seaweed farming nor the merchant of marine prod- ucts. This is because agriculture produces less satisfactory results. Another source of income is derived from a sideline business such as making coconut oil, weaving mats, handyman, labor services, business accommodation and much more. Residents of Javanese tribe have a culture of communal work and a deep-rooted kinship system, as well as other maritime ethnicity. It is characterized by sambatan tradition with various terms, namely the system of communal work in order to build a house, help people who have events or celebration, clean villages, mosques, and other means (Endraswara 2010).

Nowadays, the descendants of Madurese community generally have a livelihood as fishermen, raise cows, goats, and make dried or salted fish as a product of domestic industry. Migrants from Madurese ethnic group come due to soil condition in Madura island which are difficult for agriculture. This has encouraged the residents to leave their place of origin with the hope of getting a better life in other sectors (Syamsuddin 2007).

Meanwhile, Madurese people generally working as fishermen, raising cattle for beef and goats, running home industry in making dried fish or salted fish. Madurese ethnic groups came to Karimunjawa due to difficult condition of homeland origin in Madura as agricultural land. They left Madura island to hope that they can obtain a better life in Karimunjawa.

Thus, the Karimunjawa Islands have become a bowl salad that bring together ethnicities from different regions with their own cultural distinctive. In some studies, it has been shown that multiethnic populated areas have high potential for communal conflict. As an illustration, in the five years between 1996-2001 there have been several conflicts that exploded as brutal violence, some of which overlap between ethnic and religious differences, the conflict between ethnic Malays and Madurese in Sambas West Kalimantan in 1996-1997 and again in 1999; Between East Timorese Christians and migrants from Bugis, Buton and Makassar (BBM) in Kupang and Soe in 1999; Between 
Ambonese Christians and BBM in Ambon in 1999; Between ethnic groups in North Maluku in 2000; Ethnic groups in Poso Central Sulawesi in 2001; and between Dayak and Madura ethnic groups in Central Kalimantan in 2001(Marzali, 2003). The list can still be extended by incorporating conflicts between the Islam Wetu Telu (three times praying) and Islam Waktu Lima (five times praying) communities in Lombok as well as between the Muslim minority and the Hindu majority in Bali (Erni, 2003). These conflicts cannot be separated from fundamental changes in Indonesian society. As Magnis-Suseno (2003) has noted, modernization and globalization have led to the disorientation, dislocation, and dysfunction of traditional mechanisms as well as the growth of primordialism that tends to lead to exclusive and aggressive attitudes toward other communities.

Although they have different cultural backgrounds and tribes, they can establish a good social relationship. The social system runs as usual, in fact there is never a conflict that disrupts the social harmony system among tribes on the Karimunjawa islands. This indicates that the population of Karimunjawa has a high social awareness and openness to accept differences. However, with the capitalist economy expansion and the growing hegemony of foreign culture which is very intensive, they will lead to changes and negative reactions from the community. Capitalist expansion can be seen from their mastery of several islands that have been purchased by the foreign community, and even strangers. Of course, if these symptoms are running without control, they will cause an imbalance in social relationship that would be the seeds of conflict (Rochwulaningsih 2011). Moreover, the Karimunjawa potential as Tourist Destination Area (Daerah Tujuan Wisata) becomes more important, especially the visit of natural attractions in the form of marine tourism.

In the context of Karimunjawa, the intensified expansion of capitalistic economy and development of external cultural hegemony can drive fundamental changes and the emergence of negative reactions from the local community. The economic expansion can be seen from controlling several islands that have been authorized by investors both Indonesian and foreigners. If it goes uncontrollably, this phenomenon will certainly create an imbalance in social relationships that will become a conflict seeds (Rochwulaningsih, 2011). Moreover, as a tourist destination (Daerah Tujuan Wisata), Karimunjawa has increasingly become more important and crowded, especially on marine tourism.

One interesting point is the phenomena that Karimunjawa people have different ethnic and cultural backgrounds, they are still take a good care of social harmony. However, the community system runs normally and never be happened conflict which affects the harmonious life and interreligious relationships. This shows that the population of Karimunjawa has a high social awareness and openness to the natural phenomena that they accept differences.

In the other words, the people of Karimunjawa have been able to develop attitude to multiculturalism. It is formed by involving a set of values based on an understanding and on respect, as well as appreciation of different cultures. Although it is not followed by written agreement of the other culture contents, but it emphasized multiculturalism is understanding, respect, and appreciation (Blum, 2001; Ahimsa-Putra, 2009). Therefore, Suparlan (Suparlan, 2002) calls multiculturalism as an ideology recognizes and glorifies differences in equality, both individually and culturally.

In that relationship, certain measures are needed in order to maintain and improve social harmony continuously despite external influences become more frequent. For this reason, this research is especially important in order to explore and identify the patterns of social interaction in the Karimunjawa people, both social interactions internally within an ethnic group, as well as social interaction between different ethnic groups. It is important to remember that even though Karimunjawa people is plural, serious social conflicts never appear. Thus, the study of the patterns of social interacti- 
on is very important as the lesson that may be applied broadly by Indonesian people who are still facing threat of social disintegration at the moment. The inter-ethnic interaction patterns in Karimunjawa which are very heterogeneous can be a social harmony model among multi-ethnic societies in another places that often face latent danger of social disharmony and even social conflict.

Based on these concepts, this research is important in exploring and identifying social interaction patterns within Karimunjawa society both internally within an ethnic group and externally among ethnic groups. Based on the background above, then this article will examine some of the following problem as follow. First, how is the pattern of social interaction in a multicultural community in the implementation of social inter-ethnic relationship in Karimunjawa? Second, how is the role of each ethnic in the social, cultural, and economic activities in the midst of the dynamic community Karimunjawa archipelago? Thirdly, how can the use and acceptance of the local wisdom of each ethnic in the harmonious interaction and social relationship support the cohesiveness of community in the archipelago.

\section{RESEARCH METHOD}

The data collection process in this study was performed through several techniques, namely; in-depth interview, focus group discussion (FGD), and observation, and literature review. In-depth interview was conducted to individual respondents by using an interview guide which had been prepared in advance. In this case, the respondent selection was determined by using the snowball sampling. The FGDs was conducted to the respondents collectively or together to discuss various issues related to the various dynamics on social interactions that underlie the creation of social harmony. The respondents included the representatives of each ethnic in Karimunjawa are Javanese, Buginese, Mandar, Bajo, Banjar and Madurese.

For a good interview activity, it was carried out on individuals and groups in order to take place effectively and efficiently. First, a personal approach to public figures from both formal and informal elements was performed. FGD aimed to obtain a comprehensive and detailed overview of the patterns of social interaction as well as the values of local wisdom of each ethnic group in Karimunjawa.

Observation was a specific way in which the researcher was not a passive observer but played various possible roles in different situations or even might play a role to direct the events being studied. In this observation, the researcher applied it in the research site where the multi-ethnic communities lived and each ethnic certainly had unique characteristics. In this case, the researcher involved in the daily life of the community while carefully observed all actions of the community in all circumstances and situations related to their socio-cultural life. During the observation, the researcher also kept the record on the things that were considered important and took a picture which was relevant to the research problems.

Data analysis in this study used qualitative data analysis. Qualitative data analysis was a search on general statements about the relationship between the various data categories to build conceptual understanding of social reality based on the findings of the empirical data. This was in line with the opinion of Patton who explained that in qualitative research, data analysis was the process of arranging the order of the data, organized them into a pattern category and description of the basic unit (Marvasti 2004). Categorizing of data was adjusted to the formulation of the question proposed in this study and was intended to provide ease of interpretation, selection, and explanation in the form of analysis description.

\section{RESULTS AND DISCUSSION}

Geographic and Demographic Condi-

tions of Karimunjawa District

Karimunjawa located in the Java Sea and included in the area of Jepara district. The- 
re are 27 islands that make up the series of Karimunjawa archipelago and there are only five inhabited islands. There are three subdistrict administrative governments under Karimunjawa, namely Karimunjawa with a population of 4,603 people, Kemujan has of 2,857 people, and Parang has 1,089 people, and Nyamuk has 557 people (Karimunjawa in Figures 2015). The majority of people work as fishermen and the others are farmers. There are three dominant ethnics occupying in Karimunjawa, they are Javanese, Buginese, and Madurese. The education level of the population in Karimunjawa is classified as low. The number of residents who are primary school graduate and not graduate has balanced number of 2,733 people. While 959 people have never been to school, another part of the population has completed the education at secondary level and above, while a few others have managed to complete the college education. Since junior high school and vocational school established in Karimunjawa, after completed primary school they can go on to higher education. After graduating from high school, they continue their education to some universities in Javanese.

Karimunjawa's ethnic diversity is a cultural condition that may have negative potential in the process of social cohesion and integration of the community as the foundation for the establishment of national integration. Meanwhile, there was a very high growth in the 1960-1970 era, and a plural country like Indonesia faces obstacles in its development because the existing ethnic diversity (Koentjaraningrat 1971). Stimulating the growth of a heterogeneous region population will be much more difficult and takes time compared to a region whose residents tend to be homogeneous, such as Japan. Furthermore, according to Koentjaraningrat, the existence of ethnic diversity harbored the possibility of ethnic conflict, which therefore needs to be understood by government officials or any other parties as a fact and not to be avoided (Koentjaraningrat 1971). Therefore, many efforts to explore and formulate the objective conditions of interethnic social relations patterns become important. It actually answers the uniqueness or specific multiculturalism model, which is still in question (Syaifudin, 2006). It can be a model because in there are media enabling interethnic society can interact equally, such as Sambatan, cleaning village (Bersih Desa). A deep thought on the need for inter-ethnic tolerance so that each party can be synergized to coexist peacefully and carry out development for the mutual progress should be considered and investigated further.

\section{Main Ethnics Formation in Karimun- jawa: Javanese, Buginese and Madu- rese}

Karimunjawa community as the archipelago community is a result of the migration process. Migration according to the theory of Harris and Todaro (1970) is triggered by differences in the income earned between business sectors in urban and rural areas (Harris and Todaro 1970). Migration to urban areas will increase if the agricultural productivity in rural areas decreased which will result in lower incomes in rural areas. Migration to urban areas also causes population density and increased unemployment especially in informal sectors. Indeed, this theory gets many objections because it only bases the migration on economic aspects alone.

Trigger of migration becomes a very broad discussion, if it is developed on the actors and where the migration process takes place. Education affects the decision to migrate. Migration actors are mostly young, well educated, have small risk, have orientation for achievement, and already have a close relationship with the contact person on the destination.

The values of local wisdom, according to Sartini (2004) are local ideas which are wise, full of wisdom, good value, embedded and followed by the local community. In this case, the multi-ethnic communities of Karimunjawa definitely have their ethnic identity-respectively and functioning in the ethnic community effectively (Sartini 2004). Banks also argued that one must have a sufficient understanding of the values of ethnic and personal identity before he positively associates with individuals from different 
ethnic groups. People need to be encouraged to accept the spirit of ethnic alone without encourage the ethic ethnocentrism. As one member of a particular ethnic, one need to feel comfortable with the ethnic and more importantly is capable of functioning in plural community. Therefore, each ethnic certainly interacts with other ethnic groups and has a way on how they solve problems or conflicts that may arise among ethnics (Banks 2006). Banks also said that a positive effect is never achieved in the plural American community, as a social institution always clicking all the Anglican-ethnic, and does not appreciate the existence of each ethnic as well as forces the establishment of ideal monocultures community (Banks 2006).

Cases in Karimunjawa community are quite the opposite. A community tends to think based on cultural and ethnic and suppresses ethnic encapsulation, so that even though they come from diverse ethnic background, they still can tolerate to live peacefully.

Karimunjawa people as the island's community has tendency to migrate due to the high dependency relationship with the centers of the economy and education. There is a pattern of center-periphery, hegemonic relationship on the remote islands (in this case is the Karimunjawa) located in the Javanese Sea, Indonesia. Also in the study, the extent to which advances in technology, information, communication, and transport play an important role in reducing the hegemonic relationship between the center and periphery areas are also examined. Based on the results, the information of pattern of center-periphery relationship in Karimunjawa archipelago community is obtained. This relationship positions the of Karimunjawa (Karimunjawa village) as the largest island and a center, while the smaller islands such as Kemujan, Parang, Nyamuk and Genting as the suburbs (periphery). The formation of this relationship pattern can be traced through the geographic and socio-historical characteristics which in politic, economic, and cultural create unequal relationship between the two. Meanwhile, the pattern of center-periphery relationship has been reduced after the communities in the periphery also gain access to technology, information, and transportation even though the levels are less than in the Karimunjawa. On the contrary this situation has actually strengthened the integration between ethnic groups in the Karimunjawa area.

The migrants of Javanese ethnic are expected to be the first resident in Karimunjawa archipelago. The oral tradition story said that Karimunjawa has been inhabited by people from the Javanese since Majapahit period. Even though this information cannot be traced further, some of the tombs of important figures in the region such as $\mathrm{Su}-$ nan Nyamplungan is believed to assert it. Information of oral tradition also tells Karimunjawa role as a gathering place of Jepara forces before attacking the VOC in Batavia under the command of Queen Kalinyamat (Interview with Sutrimo, May 29, 2016).

During the Dutch East Indies period, Karimunjawa also became the center of copra. The copra product was marketed to Javanese through Chinese middlemen to Semarang, Pekalongan, and Surabaya. Through the Chinese traders, some Javanese laborers and workers also began to come to Karimunjawa. In Karimunjawa, they reside, married local women, and began to fill the area. The migrants from Jepara and Semarang were Javanese migrants who were quite dominant in the region. Since the government made an administrative arrangement in the 1950s$1960 s$, Karimunjawa also became one region to be laid out. Employees and local officials from Javanese gradually began to come to Karimunjawa. Due to the need to improve the education standard in Indonesia, the government began the establishment of some schools at basic level in the region since the 1970 s and 1980s. In addition to buildings, the government also sent several teachers to the region. In average, they were Javanese migrants from Jepara (north) and Klaten and Yogyakarta (south). In line with that action, the establishment of sub district level police office (polsek) and the Military Command (Koramil) of Karimunjawa also be a way for the influx of the next Javanese mi- 
grants. Most of the teachers and employees of Protestant and Catholic formed a Christian community in the area. Their existence is also marked by the establishment of the Pentecostal Church in the 1980 os.

Javanese culture and tradition are very dominant in the Karimunjawa village (including Genting) and Parang. In both regions, the use of the Javanese language is easy to find, even if the speaker has not Javanese background such as Buginese. In addition to the language, ritual of salvation, circumcisions, and marriages are closely related toto coastal Javanese culture are easily found in these areas.

Along with the arrival of the Javanese, the Madurese also began to come to this region.They came from Sampang, Bangkalan and Pamekasan or from other islands such as Masalembu. The arrival of the Madurese who have two livelihood bases namely agricultural and maritime also began to intensify the activity of raising cattle. Cows are animals that are always attached to the Madurese ethnic, not only in Madurese but also in Karimunjawa. In Karimunjawa, Madurese inhabit the area of Karimunjawa, AlangAlang, and parts of Kemujan. In addition, they also inhabit Nyamuk and Parang.

Buginese people began to come to Karimunjawa in the 1950s.The generation Buginese believe that the migrants in Karimunjawa have existed before the 1950s. For example, it is strengthened by some statements of the Buginese elders. In Karimunjawa, Buginese are concentrated in the Batulawang, Kemujan. Nonetheless, the Buginese are also scattered in other areas outside Kemujan. In addition to be known as a sailor and strong in in the fisheries sector, the $\mathrm{Bu}-$ ginese in Karimunjawa also engage in the production of copra, a main stay production in Karimunjawa (Suliyati 2016). Moreover, they are also known as traders and excellent boat makers. The shape of Karimunjawa ship is distinctive and different from the shipform on the north coast of Java, this is believed to be affected by the shape and model of Buginese phinisi.

\section{Inter-ethnic Interaction patterns in Karimunjawa}

As the islands, Karimunjawa has geographical character as an open zone or area which would have a significant effect with the character of its inhabitants, the people who settled in Karimunjawa. They are very mobile which is affected by the monsoon winds direction in which the monsoons wind cycle has been facilitating the mobility of people between islands in Karimunjawa archipelago as well as with outsiders. This allows for specific cross-cultural interaction in Karimunjawa archipelago community.

Open geographical character has contributed to the ways of looking at the various ethnic groups in the Karimunjawa on the sea existence. In this context, they tend to see the sea as an open space that can be utilized by all people without considering the ethnic and culture background. Everyone is considered to have the same right to take advantage not only for the daily needs of the economy (such as fisheries) and but also to the means of transport and communication. Traditionally, the sea is seen as common property right that can be used together. Such system of the use of sea works in harmony and stimulates the formation of interethnic patterns, equal interaction away from competition climate and unhealthy conflict (Suliyati 2013).

The description of the interaction patterns of intra ethnic communities in the Karimunjawa archipelago can be seen in the following. There is a story of three families with different ethnic, namely the family of Arif Ali, and Sakim who have been living sedentary (embryo) in the Karimunjawa. Arif and his wife is a couple who inhabit Karimunjawa. They married 15 years ago and now have two children. Arif admits that he has Mandarese blood, but his wife is a woman from Javanese ethnic. Although Arif has Mandarese blood, he is happier and more comfortable to be referred to as a Javanese. In everyday life, they also use Javanese identity, both speech use, relationships patterns built between family members, and between members of the family with other 
families. He also admits that Javanese values are inherited in his family. Nonetheless, the Javanese values in question do not refer to the orientation of mainstream Javanese as Yogyakarta and Solo, but the value of the north coast of Javanese and based on the ethics of students.

The same applies to Matius Slamet and his wife, Suzanna. He comes from Batang and his wife is from Temanggung, Central Javanese and they build communication patterns in families with the values of Javanese culture. For example, it appears in the case of the use of the Javanese. But apparently, the typical coastal Javanese is more dominant. Although embraced Christianity, Slamet also held selamatan when their son's circumcision.

In the Buginese family, it is seen from the life of Ali who is a Buginese and his wife is Madurese. Ali's family is a mixed picture of Buginese and Madurese. However, they use the patterns of inter-ethnic communication and Javanese values. Explicitly, it is seen at the use of the Javanese Jeporoan, by the family members both when communicating at home and in the milieu. This is in contrast with the same case applied in Abdullah family in Batulawang, Kemujan. Apparently, the different social context causes different inter-ethnic interaction patterns. Abdullah family who lives in an environment dominated by Buginese culture seemed to be more eloquent in practicing Buginese values in everyday life. Abdullah's wife who is a Javanese ethnic looked more like Buginese than Javanese.

It is slightly different in the case of Muhsin who is a Mandar and his wife who is from Javanese (Cilacap). As a man of Mandar who lives in Kemujan, Muhsine fluently speaks Buginese, Mandarese, and a little bit Madurese. That skill is the key to the smoothness of the interaction he has done in the community. In Kemujan, it is not strange if someone mastering more than one mother tongue. However, Mukhsin wife cannot speak Mandar and Buginese. She chooses to use the Javanese in everyday interactions. Sulaiman is a Buginese and his wife from Javanese ethnic (Demak). It is just three months after they got married but his wife has been in charge of the Buginese language. In communicating, they use Buginese language, including in children. In the Parang region which is dominated by Javanese culture, and migrants from the north coast of Javanese uses Javanese in everyday interactions. Although there are migrants from Flores and Madurese, they are not dominant. This condition is similar to Genting. Genting is almost 100 Javanese. There is only one Madurese, but this person has been married to Javanese and everyday uses Javanese language of coastal area (Jepara) which tends to ngoko (informal).

\section{CONCLUSION}

People in the Karimunjawa archipelago are all immigrants who come from various regions in Indonesia with the various ethnic background such as Javanese, Buginese, Makassarese, Madurese, Bajo, Banjar, Buton, and others that almost everything can be referred to as maritime ethnic, because it is based on their livelihood on the sea. Their perspectives on the sea existence is proved to affect the pattern of social interactions despite the various ethnic background/multicultural, but they build a harmonious social relationship and tolerate each other.

The perspective is related to the geographic characteristics of the Karimunjawa archipelago as an open zone or area where they tend to see the sea as an open space that can be utilized by all people without considering the ethnic and culture background. Everyone is considered to have the same right to take advantage not only for the daily needs of the economy (such as fisheries) and but also to the means of transport and communication. Traditionally, the sea is seen as common property right that can be used together. Such system of the use of sea works in harmony and stimulates the formation of patterns of inter-ethnic, equal interaction away from competition climate and unhealthy conflict. 


\section{ACKNOWLEDGEMENT}

This article is part of boarder research Riset Penerapan dan Pengembangan, entitled "Pola-pola Interaksi Sosial pada Masyarakat Plural: Studi Kasus Masyarakat Maritim di Karimunjawa“, funded by LPPM Undip 2016. Research team consists of Titiek Suliyati, Yety Rochwulaningsih, and Mahendra P. Utama.

\section{REFERENCES}

Ahimsa-Putra, H. S., (2009) Dari Plural ke Multikultural: Tafsir Antropologi atas Budaya Masyarakat Indonesia. Yogyakarta.

Banks, J. A., (2006). 'Ethnic Studies as A Process of Curriculum Reform', in Race, Culture, and Education. New York: Routledge Taylor and Francis.

Blum, L. A., (2001). 'Antirasisme, Multikulturalisme, dan Komunitas Antar-Ras: Tiga Nilai yang Bersifat Mendidik bagi Sebuah Masyarakat Multikultural', in May, L., Collins-Chobanian, S., and Wong, K. (eds) Etika Terapan I: Sebuah Pendekatan Multikultural. Yogyakarta: Tiara Wacana.

Erni, B., (2003). 'Mempertahankan Identitas dan Toleransi Antaragama: Minoritas Muslim di Lombok dan Bali', in Stokhof and Djamal, M. (eds) Konflik Komunal di Indonesia Saat Ini. Jakarta: INIS Universiteit Leiden dan Pusat Bahasa dan Budaya Universitas Islam Negeri Syarif $\mathrm{Hi}^{-}$ dayatullah, pp. 35-52.

Hamid, A., (2005). Passompe Pengembaraan Orang Bugis. Makassar: Pustaka Refleksi.

Harris, J and Todaro, M. . (1970) 'Migration Unemployement and Developement: A Two Sectors Analysis', American Economic Review, 6o(1), pp. 126-142.

Kesuma, A. I., (2004). Migrasi dan Orang Bugis. Yogyakarta: Ombak.

Koentjaraningrat (1971) Manusia dan Kebudayaan di Indonesia. Jakarta: Djembatan.

Magnis-Suseno, F., (2003). 'Faktor-faktor yang Mendasari Terjadinya Konflik antara Kelompok Etnis dan Agama di Indonesia: Pencegahan dan Pemecahan', in Stokhof and Djamal, M. (eds) Konflik Komunal di Indonesia Saat Ini. Jakarta: INIS Universiteit Leiden dan Pusat Bahasa dan Budaya Universitas Islam Negeri Syarif Hidayatullah, pp. 119-132.

Marvasti, A., (2004). Qualitative Research in Sociologi: A Qualitative Method. London: Sage Pub- lication.

Marzali, A., (2003). 'Perbedaan Etnis dalam Konflik: Sebuah Analisis Sosio-ekonomis terhadap Kekerasan di Kalimantan', in Stokhof and Murni Djamal (eds) Konflik Komunal di Indonesia Saat Ini. Jakarta: INIS Universiteit Leiden dan Pusat Bahasa dan Budaya Universitas Islam Negeri Syarif Hidayatullah, pp. 15-26.

Muhammad, S., (2007). 'Migrasi Dan Orang Madura', Aplikasia: Jurnal Aplikasi llmu-ilmu Agama, 8(2), pp. 150-182.

Muhammad, S., (2016). 'Social Network of Bugis Weavers at Wajo Regency, South Sulawesi', Komunitas: International Journal of Indonesian Society and Culture, 8(1), p. 155. doi: 10.15294/ komunitas.v8i1.3437.

Paeni, M., (1995). Sejarah Kebudayaan Sulawesi Selatan. Jakarta: Departemen Pendidikan dan Kebudayaan RI.

Pelras, C., (2006). Manusia Bugis. Jakarta: Nalar.

PemerintahKarimunjawa, (2014). Kecamatan Karimunjawa Dalam Angka. Karimunjawa.

Rochwulaningsih, Y. (2011) 'Land Tenure in a Remote Islands: A case of a historical sociology prespective in Karimunjawa', Journal of Coastal Development, 15(1), pp. 82-93.

Rochwulaningsih, Y., (2012). 'Marjinalisasi Etnik Maritim: Studi Kasus di Kepulauan Karimunjawa', in Karsidi, Asep, Sobar Sutisna, A. P. (ed.) NKRI dari Masa ke Masa. Jakarta: Sains Press, pp. 128-138.

Rochwulaningsih, Y., (2015). 'The Role of Social and Cultural Values in Public Education in Remote Island: a Case Study in Karimunjawa Islands, Indonesia', Komunitas: International Journal of Indonesian Society and Culture, 7(1), pp. 25-36. doi: 10.15294/komunitas.v7i1.3336.

Sartini. (2004). 'Menggali Kearifan Lokal Nusantara Sebuah Kajian Filsafati', Jurnal Filsafat, 37(2), pp. 111-120.

Suliyati, T., (2016). 'Harmoni dalam Pelestarian Budaya Etnis Bugis di Kepulauan Karimunjawa', Sabda (Jurnal Kajian Kebudayaan), 11, pp. 6171.

Suparlan, P., (2002). 'Menuju Masyarakat Indonesia yang Multikultural', Antropologi Indonesia, Indonesian Journal of Social and Cultural Anthropology, XXVI(69), pp. 98-105.

Syahadat, R. M., Arifin, N. H. S. and Arifin, H. S., (2014). 'Public perception on historical landscape of ethnic immigrant heritage in Heritage City of Baubau', Jurnal Komunitas, 6(2), pp. 189-196. doi: 10.15294/komunitas.v6i1.3310.

Syaifudin, A. F., (2006). 'Membumikan Multikulturalisme di Indonesia', Jurnal Antropologi Sosial Budaya Etnovisi, 2(1), pp. 3-11. 